\author{
Gordana Mišev \\ Ministry of Mining and Energy, Belgrade
}

\title{
Projects of the New Silk Road in Central East Europe with a special look at the Republic of Serbia
}

\begin{abstract}
After the establishment of the cooperation mechanism between China and Central European countries ("16+1"), Serbia became one of the most active participants in this project. In this sense, Serbia's role is extremely important because the country is connected to Central and West Europe by its position on the New Silk Road and, therefore, it is on the crossroads of important land and river routes. China's geostrategic interest in this part of Europe is primarily economic - for the most part as a transit area to the West and much less as a potential market. The West is suspicious of China's intentions, and the benefits that Central East European countries will have from China's breakthrough, the realization of the New Silk Road project, depend on the capability and will of the political power carriers. Due to good Sino - Serbian relations, the Republic of Serbia starts up more and more practical projects of cooperation with the intention of creating conditions for a stable and sustainable economic development.
\end{abstract}

Keywords:

infrastructure, projects, China, economic development, Central East Europe

\section{INTRODUCTION}

What characterizes the world order today is not the lack of bipolarity or multi-polarity, but the division of political and economic interests with the geopolitical ambitions of the world powers, which leaves room for redefining roles in international relations. With the end of the Cold War and the fall of 
communist regimes in Eastern Europe and the USSR, few countries keep a stable communist government, of which China has the largest international influence. For more than 20 years, China's breakthrough on the world stage has not been characterized by military expansion, but rather by economic expansion: the Chinese Yuan has finally become an international currency, China has become a member of the European Bank for Reconstruction and Development (EBRD). Due to its initiative, the New Development Bank (BRICS Development Bank) has been founded, and as a pinnacle of economic development, in 2013, China launched the "One Belt, One Road" initiative, which is one of the largest economic ventures in globalization. In the post-bloc era, apart from Russia and China, there is a noticeable strengthening of other countries which could find their place on the global map as carriers of multi-polarization (Brazil, India and South Africa). Their breakthrough is followed by a strategic integration precisely with Russia and China through international, primarily economic, but also military organizations such as BRICS and SCO (Shanghai Cooperation Organization: Kazakhstan, China, Kyrgyzstan, Russia, Tajikistan, and Uzbekistan, where the affiliated members are India and Pakistan). Cooperation in 2016 was strengthened by forming a multilateral development bank: Beijing-based Asian Infrastructure Investment Bank (AIIB), with 87 members worldwide (including the United Kingdom, Russia, Germany, United Arab Emirates, Norway, France, Qatar, India, etc.). By working with Russia and other member states of the Shanghai Cooperation Organization, the Eurasian Economic Community, and the BRICS, China maintains a balance of power and influences the establishment of multi-polarization in international relations (Timothy R., Kristen, \& Cortez A., 2018).

Extending to $9.596 .960 \mathrm{~m}^{2}$, accounting for two-thirds of the East Asian space, with a population of 1.3 billion, making up one-fifth of the world's population, with the world's most dynamic economy, armed with nuclear weapons and being one of the five permanent members of the UN Security Council, the People's Republic of China is a country with superpower potential at the beginning of the 21st century (Brzezinski, 1999). According to the IMF report, China is the second-largest in terms of economic strength based on nominal GDP, has the highest purchasing power parity, and is also the largest exporting country, i.e. trade power (IMF, 2017). In terms of total military potential, China is ranked third among 136 countries in the world (GFP, 2018), and according to budget allocations for the military power, it is ranked second (Perlo-Freeman, 2014). China's "New Silk Road" strategy focuses primarily on improving the economic, financial, cultural, scientific and technological cooperation with countries in Asia, Africa, and Europe in order to achieve overall progress, regional security and achieve internal 
political stability and economic prosperity. The 'New Silk Road' is a huge undertaking, spanning across 70 countries through two trade routes (land and sea) to better connect China with other countries.

\section{THE REPUBLIC OF SERBIA AND THE "16+1" INITIATIVE}

Serbia is a small continental country $\left(88.361 \mathrm{~km}^{2}\right)$, located mostly in Southeastern Europe and to a lesser extent in Central Europe. Serbia ranks 48 in the World Bank's Doing Business list for 2019, with a constant GDP growth over the past few years, which is $3.8 \%$ in the second quarter of this year (SORS, 2018), which is higher than the International Monetary Fund's forecast of 3.5\%. Its largest economic sector is services (over 60\%), followed by industry and agriculture. However, more than a quarter of a century since the collapse of socialism in Southeast Europe, this region, including Serbia, has failed to catch up with the developed countries of the West economically. Serbia, with its collapsed economy after the sanctions and wars of the 1990s and unresolved issues of the southern province, is trying to find its place and impose itself as a regional leader, at least in the Balkans.

After the establishment of "16 +1 "1, the cooperation mechanism between China and the countries of Central and Eastern Europe CEEC (11 are members of the European Union and 5 countries of the Balkans), Serbia became one of the most active participants. The Republic of Serbia has special significance for China, because of its position on the "New Silk Road" that connects it with Central and Western Europe by two routes, the first being the southern gate of Europe from the Greek ports of Piraeus and Thessaloniki through the railway-road corridor to Northwestern Europe (through Serbia to Hungary and further to Austria and Germany). The second one connects Eastern Europe through Russia, Turkey and Bulgaria using the Black Sea basin and ports in the region, then across the Danube to the Rhine-Main-Danube canals to the major ports of Rotterdam and Hamburg and also to Western Europe. The project New Silk Road involves upgrading and extending the existing ones, and building brand new road and sea corridors and logistics along the way (road, water and air corridors, ports, industrial parks, energy projects, etc.). The importance of establishing a strategic partnership between Serbia and China has positive effects on

Cooperation between China and Central and Eastern European Countries (CEEC): http://www.china-ceec.org/eng/ 
optimizing Serbia's foreign policy position in international relations and on consolidating its position within the " $16+1$ " mechanism. This mechanism is established with the purpose of strengthening co-operation between China and the countries of Central and Eastern Europe, and implementing the goals of China's "New Silk Road" development strategy and its initiatives "Silk Road Economic Belt" and the "21st Century Maritime Silk Road", briefly referred to as "One Belt, One Road" (OBOR). So far, the hosts of "16+1" summits which take place every year have been Warsaw (2012), Bucharest (2013), Belgrade (2014), Suzhou (2015), Riga (2016), Budapest (2017) and Sofia (2018).

Thanks to good Sino-Serbian political relations, more and more practical cooperation projects are being launched. The first major step, considered to be a complete intensification of relations between the two countries, was made in 2009 when the Agreement on Economic and Technical Cooperation in Infrastructure Projects was signed and further strengthened within the '16+1'platform. It should be noted that Serbia is the first country in Europe the Chinese citizens need no visa to enter (and vice versa). China and Serbia have been improving their economic relations for years, mainly through important infrastructure projects in various fields, such as,

- Energy: (China National Machinery and Equipment Import \& Export Corporation (CMEC) is participating in the construction of a new block of TPP "Kostolac B" and the expansion of the Drmno surface mine. China Environmental Energy Holdings (CEE) and Shenzhen Energy Group (SEC), in a consortium with "Electric Power Industry of Serbia ", participate in the construction of Block 3 of TPP" Nikola Tesla B ");

- Infrastructure: (China Road and Bridge Corporation (CRBC) built Zemun - Borca Bridge (Pupin Bridge); China Railways International and China Construction Company will do the works on Belgrade Budapest railway line (MGSI, 2918) (350km) /works already started on the $75 \mathrm{~km}$ long railway line from Belgrade to Novi Sad /; China Shandong International Economic \& Technical Cooperation Group Ltd. Of Shandong Hi-speed Group Co. Ltd. and Shandong Hi-speed Group Mansion built the Obrenovac - Ub $(51 \mathrm{~km})$ and Lajkovac Ljig sections of the E 763 turnpike (MGSI-E763, 2012); signing the memorandum of understanding on the reconstruction of Belgrade - Nis Railway Line, which is a highly important railway section when it comes to connecting the Piraeus Port and Central Europe; Signing a framework agreement between the Government of Serbia and China on giving Serbia a concession loan for the realization of Belgrade bypass construction project, and the contract on the state 
concession loan for the Belgrade Bypass construction project as part of E70 / 75 turnpike, the section Bridge across the Sava near Ostružnica - Bubanj Potok);

- Mining: (Zijin mining group became a strategic partner (63\%) of RTB Bor as of January 1, 2019) (MRE, 2018);

- Metal Processing Complex (Hestil - Smederevo Ironworks) (HBIS, 2018);

- ICT sector (Through Huawei Technologies, China participated in the modernization of the Integrated Telecommunication System "Serbian Railways");

- A Mei Ta Company factory, producing car parts, was opened in Obrenovac. The opening of a Shandong Linglong Tire Factory was announced, which means that China will invest \$ 1 billion in this new factory in Zrenjanin;

- Borca Industrial Park CRBC (China Road and Bridge Corporation) China's largest industrial park in Europe - is also planned.

Figure 1. Serbia and the "New Silk Road" (IN4, 2018)

(Europe (The Baltic Sea); Russia; Central Asia; China. Europe; the Mediterranean Sea; the Persian Gulf; Western Asia. South Asia; Southeastern Asia; the Indian Ocean. China: the South China Sea;

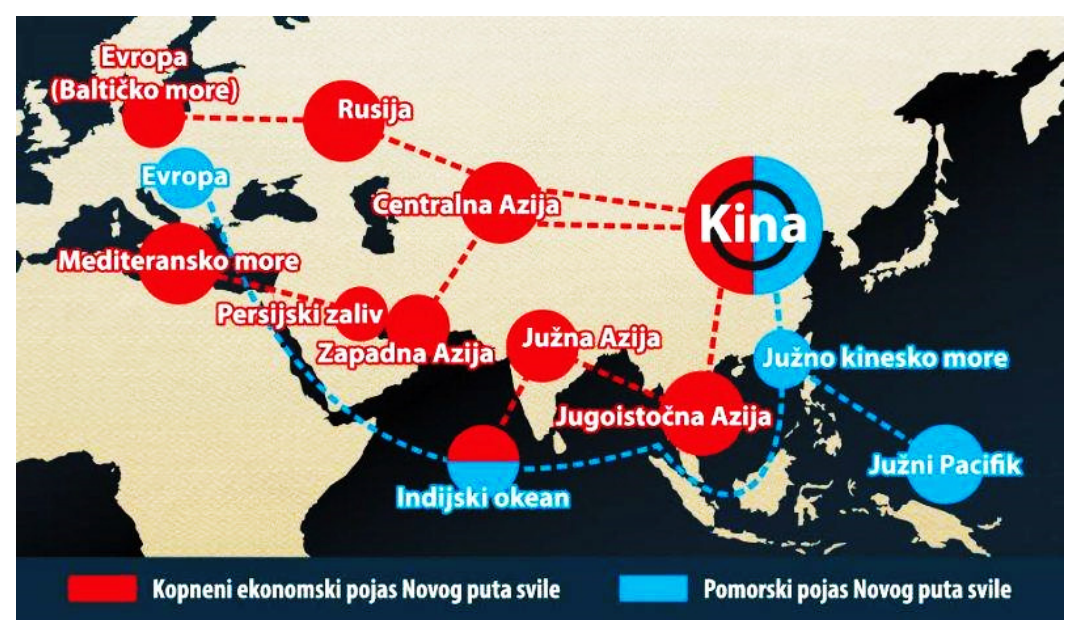


the South Pacific) Land economic belt of the New Silk Road Maritime belt of the New Silk Road

After Hungary, the Bank of China (NBS, 2018) opened in Serbia in 2017. It covers the whole of Southeast Europe. It is logical that by realizing infrastructure and transportation projects (mainly financed through loans from major Chinese state-owned banks), China will invest its highly accumulated foreign exchange reserves and engage its large civil engineering and other companies. Together with China Investment Corporation and Export-import Bank, China Development Bank is the co-founder of the 'New Silk Road Fund', established in 2015, with the initial capital of 10 billion dollars. The users of this Fund are 16 CEE countries (VPI, 2014).

\section{CENTRAL EAST EUROPE AND THE '16 +1' INITIATIVE}

Chinese investments within the ' $16+1$ ' initiative are mostly used by Hungary and Serbia, while other countries use them to a lesser extent. Greece, although not formally a member of the $16+1$ initiative, is the focus of Chinese state investment. Greece is very significant because it is the southern gateway to Europe. Chinese state-owned electric power company took over 24 percent of ADMIE, Greek power distributor in 2016, and the same year Chinese firm COSCO took over the Piraeus Port in Greece. In addition to Piraeus, COSCO invested in port infrastructures in Albania and Montenegro. Montenegro received a loan from China's Exim Bank in the amount of 809 million euros (about $\$ 937$ million) with an interest rate of 2 percent for the first section of the turnpike from Bar to the border with Serbia, to be built by CRBC (CEEC, 2018). Croatia and China signed a Memorandum of Understanding and Cooperation in the area of ports and port industrial parks in 2016, and apart from announcing the investment of $€ 30$ million in the tourism potentials of Krapinske Toplice and the contract on the construction of the strategically important Peljesac Bridge, there are no serious changes in this form of cooperation. The electric vehicle manufacturer Rimac Automobili (founded in 2009) signed a $€ 30$ million deal with the Chinese company Camel Group Ltd (CEEC, 2018). This way, the largest battery and accumulator company in Asia will finance the development of new models of electric cars and bicycles in Croatia. An investment in the Tuzla Thermal Power Plant is planned in Bosnia and Herzegovina, and a memorandum was signed to grant a 42-kilometer turnpike concession that will connect Banja Luka and Prijedor with a total 
value of $€ 297$ million (Xinhua, 2018). As far as Bulgaria is concerned, China is interested in restarting the Belene Nuclear Power Plant on the Danube, and building turnpikes and railroads. The Chinese HNA Group is granted a Plovdiv airport management concession for 35 years, which "raises high hopes for faster penetration of Chinese companies and investments in the Bulgarian market and boosts Bulgarian exports to China" (China - CEEC, 2018). China's interest in the region is primarily focused on the purchase and construction of road networks for faster transportation of Chinese goods and services. In this regard, two major Black Sea ports in Bulgaria: Burgas and Varna have maritime connections with major Chinese seaports such as Ningbo. This is a direct link to the Danube Corridor VII. Kozienice Substation Expansion and Reconstruction Project in Poland by Chinese Pinggao Group Co., Ltd. is the first general contract for electricity transmission and transformation projects completed by a Chinese company in the European Union. Chinese car maker BYD opened its first European electric bus factory in the northern Hungarian city of Komárom. BYD is expected to invest a total of $€ 20$ million in the project (CEEC, 2018). The Chinese sector FinTech came to Lithuania, which helps the two countries cooperate in the field of banking supervision, changes in the financial sector, and expand the possibilities of trade relations between the European Union (EU) and China (CEEC, 2018).

Chinese investments in Central Eastern Europe have been steadily rising for years. With the economic power, there is a growing cultural influence of China in this region. In addition to concrete infrastructure projects and the acquisition (recapitalization, strategic partnerships) of enterprises, China's influence is expanding with the help of the so-called soft measures. Those include the fields of politics, culture, art, and film production. For example, supporting the opening of a Chinese restaurant in Prague, photo exhibition "Belt \& Road" in Romania, shooting the first Sino-Serbian co-production film in Belgrade, the establishment of Confucius Institutes in Belgrade and Novi Sad, joining the Estonian Opera Festival, promoting Chinese folklore in Estonia, organizing "Chinese Modern Film Weeks" in Warsaw, etc. (CEEC, 2018). China has always had an attractive traditional culture, which is why it opened 1500 Confucian institutes around the world, so as to teach about languages and cultures. Although extremely pluralistic and diverse, China is one of the oldest civilizations and its unity can be seen in efforts to preserve the Chinese civilization as a cultural entity. Attempts were made by the West to impose its values of democracy and liberalism as universal values, to maintain its military dominance, and to expand its economic interests, increase the risk of other civilizations implementing countermeasures (Huntington, 1998). However, China still lacks a cultural 
industry, such as the American Hollywood, universities are lagging behind those in the West, and the media and the internet are state-controlled. Therefore, China must find a way, in Europe, to benefit from the enlarged area of trans-continental European co-operation in trade, communications, investment, and education.

\section{POSSIBLE RISKS OF CHINA PENETRATING CENTRAL EAST EUROPE}

Although some EU countries welcome the construction of infrastructure, paid for and built by China, others fear wider Chinese influence in the volatile countries of Central and Eastern Europe. Despite the fact that "16 + 1" was presented as a pure investment initiative, it entails intense political engagement. China made a huge impact in recent years and is in the process of making an even greater impact, not only in the Western Balkans, but throughout Europe. However, the One Belt - One Road initiative still has weak institutional structures (secretariat and national coordinators). The ' $16+1$ ' cooperation mechanism is implemented through the ChinaCIEC Cooperation Secretariat, which is an institution of the Chinese Government. Also, China prefers to negotiate bilateral projects, often without public bidding, while the European Union advocates multilateral treaties and transparent and public tenders. Finally, one should distinguish between direct investments by Chinese firms on the one hand and relatively favorable loans on the other. China finances projects primarily in the form of loans, thus threatening the underperforming economies with potentially negative consequences. Big loans can put small countries in a serious debt crisis.

The Center for Global Development in London estimates that out of 71 countries, users of OBOR credit line, eight more in addition to Sri Lanka and Malaysia, have a serious loan repayment risk: Djibouti, Kyrgyzstan, Laos, Maldives, Mongolia, Montenegro, Pakistan and Tajikistan (Panday, 2018). By analyzing Chinese measures to this date on the "New Silk Road", even the IMF warns of the risk of indebtedness of countries involved in infrastructure projects under this Chinese initiative (Lagard, 2018). It is estimated that due to the inability of those countries to repay those loans, China will turn its claims into capital, meaning that it will become the (co) owner of Gwadar and Hambantota ports, which, if converted into naval bases, will allow the Chinese Navy a permanent presence in the Indian Ocean. Sri Lanka, unable to repay its accumulated debt to China, formally handed over 
its strategic Hambantota port to Beijing for a 99-year lease by agreement in 2017 (Mitra, 2017). A similar fate is predicted for the Doraleh container terminal in Djibouti and the important maritime route. However, China prefers political stability and responsible and professional governance, as Beijing promotes cooperation with countries above all else. China does not show political destructiveness against the countries of Asia, Africa, or the countries of Central and Eastern Europe, but it uses democratic and political deficits to create economic opportunities. The European integration of the countries of the region is definitely a slow and complicated process, obtaining funding from European institutions for infrastructure projects is also a complex and conditional process, especially in recent times when the EU is focused on its own problems. This leads to many countries in the region turning to China, as it is easier and faster to get funding for these purposes. As Joseph Nye (a professor at Harvard University) stated, in 2010, China was the headquarters of two of the largest banks and four of the ten largest banks in the world (Nye, 2012). No one can dispute the fact that China is considered to be a great power. That is why every country has the right, and should consider cooperating with China. According to some estimates, Chinese investments in Germany exceed the total funds allocated to CEE countries and these investments are undisputed. Many Chinese companies are active in Serbia and the wider region of Central and Eastern Europe. The Republic of Serbia, like all countries in the region, currently has a large foreign trade deficit with China, which is expected, given the fact that Serbia does not have enough production capacity to supply the Chinese market with a sufficient quantity of certain products. China, on the other hand, has great potential and a number of opportunities, and it is not difficult for it to not only supply this market with its products, but also to invest part of its free funds in infrastructure projects.

The region of Western Balkans is always perceived as a place of confrontation between the geostrategic interests of the great powers, the West, i.e. the EU and the United States, on the one hand, and the East, above all Russia and China on the other. Russia is not the only one of the most powerful nuclear and military powers, but also one of the strongest economies and business states of the world, which, by developing its economy, turns its policies towards China, same as the EU, but also to India and the Pacific (ASEAN countries), Turkey and the Middle East. In contrast to Russian and American interests, China's geostrategic interest in Central and Eastern Europe is primarily of an economic nature - largely as a transit area to the West and only a smaller part as a possible market. It does not have (or at least does not exhibit) ambitions for domestic policymaking or regime change, as the West and Russia have. Baldwin does 
not perceive power as an absolute category, but rather as relative potential which enables it to achieve certain goals (Baldwin, 2016), which is why the West is in fact afraid of Chinese expansion. When we are acquainted with the current positions of China and Russia and the growth of their global power and influence, we can understand, more easily, the battle of great powers to take over various parts of the world (including the Balkans) and the needs of the Euro-Atlantic countries, in particular, to take control over both the transportation and energy corridors and key raw material resources. The economy, thus, becomes a tool of power, allowing control and smooth exploitation of resources and transportation of goods. The US and China are already waging a trade war and have political quarrels, instead of tackling, together with the EU and Russia, the issues of fostering a possible transcontinental system of security and cooperation with those who significantly exceed a loose and anarchic international structure. The possibility for the EU to benefit from the 'New Silk Road' is best illustrated by the fact that several of Europe's largest countries, including the United Kingdom, France, Germany and Italy, support China in creating a new international development bank, the Asian Infrastructure Investment Bank.

The West is suspicious of China's efforts to find a springboard at the borders of the European Union. One of China's rise critics, Joseph Nye, believes that Chinese state-owned enterprises are inflexible to the demanding global market, which (without questioning the ownership structure of, let's say, the leading Western energy companies), proves to be an incorrect claim just by buying a business and building infrastructure on the New Silk Road. Still, in his opposing views, Nye acknowledged that China constantly demonstrates the ability to organize the Olympics, build fast railroads, stimulate economic development, have the strongest banks, etc. What worries him is that their military power grows with the economic power, but he does not limit it only to the two types of power, he also extends it to political power and influence (Nye, 2012) without explaining what that Chinese political influence would change in Europe or the world. Other authors have a similar view, so Jacques Martin states that emerging powers use economic power to spread political, cultural, and military power and influence. In this sense, China, which has a communist system of government, does not fit into any Western models of development. The dominant Western view is that globalization is a process by which the rest of the world should become Western, by adopting free markets, importing Western capital, privatization, the rule of law, human rights, and democratic norms (Jaques, 2012). In this regard, Chinese policy does not have strict demands, nor does it enter into the social arrangements of the country 
with which it cooperates, or the culture which prevails. It does not impose its political or cultural imperatives, although it does work on its cultural promotion. China's main driving force is the economy and (self) economic interest. According to Goldman Sachs, the three largest economies in the world, by 2050, will be China, America and India, followed by Brazil, Mexico, Russia, and Indonesia. European countries, once leading powers of the world, the United Kingdom and Germany, will, respectively, be ranked ninth and tenth (Wilson \& Stupnytska, 2007). This is best illustrated by the fact that the leading BRICS countries will have more global influence than the G7's most developed industrial countries (France, Germany, Italy, Japan, Canada, United Kingdom, and the United States).

\section{CONCLUSION}

The One Belt, One Road initiative could revitalize European economies, promote sustainable development and create an endless path for economic and cultural cooperation which would take into account the interests of all participants. The countries of Central and Eastern Europe are aware that economic growth should be accompanied by a modernization of existing and construction of new infrastructure networks, mainly relying on loans and grants from European financial institutions, but increasingly turning to Chinese lenders. However, increased levels of debt pose a threat to macroeconomic stability, especially if loans continue to be a major source of finance investments. Therefore, it is desirable to think intensively about alternative options for financing, such as public-private partnerships, i.e. concessions, without further borrowing. Infrastructures in Serbia, Macedonia, Bosnia and Herzegovina, Montenegro and Albania are funded through the European Investment Framework for the region of Western Balkans (Projects of Energy Community Interest (PECI)), which is a mix of loans and grants, and the Chinese Belt and Road Initiative, which is based solely on loans. What European and Chinese financiers have in common is that they direct most of their investments into transportation and energy infrastructure and that their use of funds is conditioned by the involvement of firms from their countries. However, unlike other global powers, China does not act through imposing its own models of cooperation, or through any model related to normative conditions, as the EU does. Large steps, such as the takeover of Bor Mining and Smelter Basin and Smederevo Ironworks, are something very useful for Serbia which it could not get from the West. These are large investments, in which no western companies were interested. After all, one of 
the worse investment ventures was the US purchase of Smederevo Ironworks (US Steel), which resulted in huge losses and contract termination.

China will have an economic impact in Central and Eastern Europe, and throughout the European Union, because both as a producer and exporter, and as an importer, it is gradually becoming a major force in the world. There is no real choice whether or not to cooperate with China, as such cooperation is necessary. What is important to achieve is profit for all participants, not just one side, in the long run. For Serbia, integration processes in the postSoviet area (Eurasian Economic Union, Organization of Collective Security Agreement, etc.) are particularly important. The Strategic Agreement of the Eurasian Economic Union (Russia, Belarus, Kazakhstan, Armenia, and Kyrgyzstan) signed with Serbia in 2016, which includes the free trade agreement, enables free placement of goods produced in Serbia on this large market of 170 million consumers, which is a huge economic and development opportunity. Due to Serbia's central position on the Danube waterway (two and a half times cheaper than railroad transportation, and six times cheaper than truck transportation), it is necessary to develop services, fleet and terminals, i.e. infrastructure and logistics for the needs of Chinese companies, whose business volume will only grow through container, river-sea, railroad and air transportation of various commodities in the fields of agriculture (grains), metal processing complex (sheets, iron ores), chemical complex (artificial fertilizer), mining, timber industry, etc. Achieving these goals will require strong policy frameworks so as to ensure high-quality projects, sufficient macroeconomic and institutional capacities in partner countries and absorb investment flows and reap the benefits.

The region of Central and Eastern Europe, especially the post-socialist countries, should be aware of the historical moment and the opportunities which open up and formulate serious development strategies and ways of realizing national goals, relying primarily on human knowledge as the most important resource. Through the "New Silk Road", the Republic of Serbia could accelerate its economic development and, in the short term, 
become a key country in the region and a mainstay for its Eastern partners by enabling enormous economic prosperity.

Translated by

Zoran Pavlović

\section{REFERENCES}

1. Baldwin, D. A. (2016). Power and International Relations. A conceptual approach. New Jersey: Princeton University Press, ISBN 978-0- 691-17038-1.

2. Brzezinski, Z. (1999). Velika šahovska ploča: Američki primat i njegovi geostrateški imperativi. Varaždin: Interland d.o.o.

3. CEEC. $(2018,115)$. Cooperation between China and Central and Eastern European Contries . Taken from China CEEC: http://www.china-ceec.org/eng/

4. China-ceec. (2018, 6 29). Belt and Road Initiative could put Bulgaria on global logistics map: expert. Taken from China CEEC: http://www.china-ceec.org/eng/ sbhz_1/t1572715.htm

5. GFP. (2018). 2018 World Military Strength Rankings. Taken from Global Firepower: https://www.globalfirepower.com/countries-listing.asp

6. Hantington, S. (1998). Sukob civilizacija. Podgorica: CID.

7. HBIS. (2018, 12 11). HBIS group Serbia iron and steel doo. Taken from HBIS group: https://www.hbisserbia.rs/

8. IMF. (2017, April). Report for Selected Countries and Subjects: China. Taken from World Economic Outlook, International Monetary Fund: https://www. imf.org/en/Publications/WEO/Issues/2017/04/04/world-economic-outlookapril-2017

9. IN4. (2018, 12 1). Srbija i novi put svile 2017. Taken from in4: https://www. in4s.net/srbija-i-novi-put-svile-ubrzani-ekonomski-razvoj-u-funkcijinacionalnog-interesa-zemlje/

10. Jaques, M. (2012). When China Rules the World. London: Penguin books, ISBN: 978-0-713-99254-0. Taken from https://www.google.com/url?sa= $\mathrm{t} \& \mathrm{rct}=\mathrm{j} \& \mathrm{q}=\&$ esrc $=\mathrm{s} \&$ source $=$ web\& $\mathrm{cd}=1 \& \mathrm{cad}=\mathrm{rja} \& u a c t=8 \& \mathrm{ved}=2 \mathrm{ahUKEwi}-$ 1x63n8rzfAhUE-qQKHRszAVcQFjAAegQIAhAC\&url=http\%3A\%2F\%2Finct pped.ie.ufrj.br\%2Fspiderweb\%2Fpdf_3\%2F4_when_china_martin_jacques. pdf\&usg=AOvVaw2Wvkb2AJPz5s4-oMF53ala

11. Lagard, K. $(2018,3)$. International monetary fund. Taken from the Forum in Beijing: https://www.imf.org/en/Countries/CHN 
12. MGSI. (2918, 12 2). Projekat modernizacije i rekonstrukcije pruge Beograd Budimpešta. Taken from Ministry of Construction, Transport and Infrastructure: https://www.mgsi.gov.rs/cir/projekti/pr

13. MGSI-E763. (2012, 11 5). Izgradnja autoputa E763, Taken from Ministry of Construction, Transport and Infrastructure https://www.mgsi.gov.rs/ cir/projekti/izgradnja-autoputa-e-763-beograd-juzhni-jadran-deoniceobrenovac-ub-i-lajkovac-ljig

14. Mitra, D. (2017, jul 20). Despite Security Assurances, Chinese Consolidation of Sri Lankan Ports Remains a Worry for India. Taken from The wire: https://thewire. in/diplomacy/hambantota-china-sri-lanka-ports

15. MRE. (2018, 12 2). Ministarstvo rudarstva i energetike. Taken from http://www. mre.gov.rs/aktuelno.php\#a379

16. Naj, D. (2012). Budućnost moći. Beograd: Arhipelag, ISBN 978-86-523-0062-4.

17. NBS. (2018, 11 12). BANK OF CHINA SRBIJA A.D. Novi Beograd. Taken from National Bank of Serbia: https://www.nbs.rs/internet/latinica/15/linkovi_ banke2.html

18. Panday, J. (2018, 11 5). The Centre for Global Development: US officials warn China's BRI could lead to debt trap, undermine sovereignty. Taken from https:// www.cgdev.org/article/us-officials-warn-china\%E2\%80\%99s-bri-could-leaddebt-trap-undermine-sovereignty-hi

19. Perlo-Freeman, S. (2014, March). Deciphering China's latest defence budget figures. Taken from SIPRI: https://www.sipri.org/node/377 